【方法】近年発見された活性酸素特異的脂質損傷，尿中 F2-iso-prostanes（F2-IP）を用い, ELISA 法で測定し, 尿中クレアチニンで補正した。医学部学生 5 回生を対象 とし, 約 1 ケ月半に及ぶ学科試験期間の前・中・後の尿 を試料とした。

【結果】単位クレアチン当たりの F2-IP 濃度は既存の報 告と同程度の值を示した，F2-IPは試験後有意に上昇し た.

【まとめ】尿中 F2-IPがメンタルストレス評価の指標と して用い得る可能性が示唆された。

（研究協力者：鹿児島大・医・阿座上和子）

22. 人間ドックにおける生活習慣と検査データとの関 連性の検討

○黑木晶子, 鎌田さよ子, 山本聖子, 下木原直美, 松岡純子, 桶谷 櫓, 瀨戸山史郎（鹿児島県民総合保健センター） 今回人間ドック受診者における検査項目や問診事項よ り生活習慣と検查内容との関連性の有無について統計学 的検討を加えた。平成 11 年度当センター人間ドックを 受診した 12,767 人を対象とした.

結果は女性より男性においてブレスローの健康的な生 活習慣に基づいた「望ましい生活習慣」をしている者に 検查項目の有所見率が低い傾向を認めた。特に39藏以 下·40歳代に多くの有意差がみられたことから，比較的 若い年代から「望ましい生活習慣」が身に付くよう働き かけることが生活習慣病予防につながると考える。

\section{3. 正常高值血圧群における諸リスクファクターの検} 討

○湯田園美由紀，森重佳代子，上片平裕美， 高田美智代, 桶谷 蕉,

瀬戸山史郎（鹿児島県民総合保健センター）

平成 13 年度の定期健診受診者のうち, 日本高血圧学 会が示す血圧の分類で正常域の範囲にあった4,813名 を，正常高值血圧群と正常または至適血圧群の 2 群に分 類し，生活習慣病に関連する項目について男女別・年代 別に比較検討し，正常高值血圧群に関しては飲酒・喫煙 との因果関係についても検討を加えた。

結果：正常高値血圧群は正常または至適血圧群に比較 して男女共にT-cho・BMIに異常を認めるものが多く， 特に男性では各年代においてその傾向を認めた．また各 項目で異常を重複する者も多く，飲酒・喫煙等の生活習 慣との関係も示唆された。こらのことより，T-cho · $\mathrm{BMI}$ ・飲酒等の生活改善指導を行うことで, 正常高值 血圧より至適血圧への移行を促すことができるのではな いかと考えられた。

\section{4. 健康診断の血糖検査有所見者に対する TQM (Total Quality Management )}

○古海勝彦, 岩政 玩, 安次富郁哉, 舟谷文男 (産業医科大・医療科学)

糖尿病の增加は産業保健でも大きな問題であり対策は 急務であるが，未だに基準值のみの判定と画一的な保健 指導が行われている。これまで受診者ひとり一人への対 応の必要性を報告してきたが，今回 T Q M 手法の導入を 検討した。

TQM は「総合的品質管理」として生産現場で用いら れる手法だが，産業保健サービスの質的向上を目的とし て, 企業の健康診断の判定と保健指導に導入し, 従来法 との比較から妥当性を検証した。空腹時血糖值 $110 \mathrm{mg} / \mathrm{d} l$ 以上を全て「受診」とした従来法に対し, 個 別データ評洒は受診者の信頼を獲得し，個別管理を目的 としたTQM 手法を加えた保健指導は，受診を拒んでい た有所見者を教育入院に向わせるなど，大きな変化をも たらした，過剩な検査は医療費増加を招くばかりか，受 診者の健診不信にも慗がる。ひとり一人への総合的指導 は, 受診者の理解と信賴を獲得し, : 受診者を自主的健唐 管理へと導く．健康診断への TQM 導入はその第一歩と 思われる。

25. 職場健診における耐糖能異常者の頝動脈エコー所 見

○人保田敬子 ${ }^{1}$, 草野 健 ${ }^{1}$, 䆶苜 修 ${ }^{1}$, 齊藤和人 ${ }^{2}$

( ${ }^{1}$ 鹿児島県厚生連健康管理センター, ${ }^{2}$ 鹿屋体去大) 【目的】学災保険において「死の四重奏」該当者の二次 健診給付が設けられたが, 今回, 耐糖能異常の動脈硬化 に及ほす影響を検討した，対象および方法：当センター で職場健診を受診した 822 人の男性を対象とした。耐糖 能により糖尿病 (59人)，境界型群（222人）正常（54 人）に分け， 3 群間での動脈硬化の評価を頝動脈エコー を用いて検討した。

【結果】内中膜肥厚は糖疗病はもとょり境界型の段階よ り有意に増加していた。また，回帰係数より糖㽷病，境 界型は加齢による肥厚の進展が正常に比べて早かった. プラークスコアは䌅尿病群が境界型, 正常より高値だっ た。

【まとめ「死の四重奏」に該当しなくても，酎桾能異常 のみで動脈硬化の危険因子であると考えられ，健診で耐 糖能異常を指摘された時点での適切な血糖の管理・指導 が, 動脈硬化進行阻止に必要と考えられた。

\section{6. 個人曝露下一作業環境把握手法の検討} 第 1 報（粉じんの把握と評価手法事例）

○林 和幸（鹿児島産業保健推進センター・ 労働衛生工学, 作業環境林测定事業所) 